\title{
Digitalisasi Sistem Pendidikan Dengan Menerapkan Pembelajaran Hibrida Melalui Rekonstruksi Hukum Menggunakan Metode Cognate Bills
}

\author{
Candya Upavata Kutey Karta Negara (a), Daeli Subrianty (b), Kamelia Desi Awaliah (c)
}

(a) Universitas Pembangunan Nasional Veteran Jakarta, upavatacandy@gmail.com

(b) Universitas Pembangunan Nasional Veteran Jakarta, daelisubrianty@upnvj.ac.id

(c) Universitas Pembangunan Nasional Veteran Jakarta, kdesi.awal@ gmail.com

\begin{abstract}
The education quality in Indonesia occupied $72 n d$ in every 79 countries according to the programme for international student assessment (PISA) survey in 2018. With literacy, mathematics, and science, Indonesia is still below average. For 18 years of assessment, the scores of students' abilities in Indonesia always under the world standard score. Remote learning carried out by the covid-19 pandemic provided a paradigm shift for Indonesian education toward digitization. This is rising a new learning concept called hybrid learning. In order to achieve a sustainable hybrid learning to improve the quality of education in Indonesia, there are several legal questions about disharmonizing regulations in Indonesia's education sector. This study purposed to know the application of the hybrid learning as a digital transformation of sustainable education in Indonesia also reconstruction of the laws in Indonesian education through the cognate bills methods in order to promote hybrid learning in Indonesia. This study using the normative legal study that uses secondary and tertiary data sources as support data. Data analysis using statute approach, conceptual approach, and analytical approach. Studies indicate that: (1) hybrid learning integrating an interface learning system with online learning as a support tool implemented in Indonesian education systems; (2) the reconstruction of legislation on the education system in Indonesia through the cognate bills method of accommodating the concept of hybrid learning can be a progressive solution in education transformation. Therefore, with emphasis and centralized effort on the education sector, it is expected to improve the quality of education in Indonesia.
\end{abstract}

Keywords: Cognate Bills; Hybrid Learning; Legal Reconstruction

\begin{abstract}
Abstrak
Kualitas pendidikan di Indonesia menempati urutan ke-72 dari 79 negara menurut hasil survei Programme for International Student Assessment (PISA) pada tahun 2018. Dengan kemampuan literasi, matematika, dan sains, Indonesia masih berada di bawah rata-rata. Selama 18 tahun penilaian, skor kemampuan siswa di Indonesia tidak pernah berada di atas skor standar dunia. Pembelajaran Jarak Jauh (PJJ) yang dilakukan akibat pandemi COVID-19 memberikan suatu perubahan paradigma pada pendidikan di Indonesia menuju ke arah digitalisasi. Hal tersebut memunculkan konsep pembelajaran baru berupa pembelajaran hibrida (hybrid learning). Akan tetapi, untuk mewujudkan pembelajaran hibrida yang berkelanjutan sebagai upaya untuk meningkatkan kualitas pendidikan di Indonesia, terdapat beberapa permasalahan hukum

berupa disharmonisasi peraturan perundang-undangan pada sektor pendidikan di Indonesia. Tujuan dalam penelitian ini adalah untuk mengetahui penerapan konsep pembelajaran hibrida sebagai transformasi digital pendidikan yang berkelanjutan di Indonesia serta rekonstruksi hukum di bidang pendidikan Indonesia melalui metode Cognate Bills dalam rangka pemberlakuan pembelajaran hibrida di Indonesia. Penelitian ini merupakan penelitian hukum normatif yang menggunakan sumber data sekunder dan tersier sebagai data pendukungnya. Analisis data menggunakan Statute approach, Conceptual approach, dan Analytical Approach. Hasil penelitian menunjukkan bahwa: (1) Penerapan pembelajaran hibrida dilakukan dengan
\end{abstract}

Jurnal

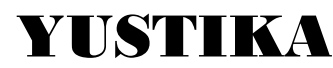

Media Hukum dan Keadilan Fakultas Hukum Universitas Surabaya Vol. 24 No. 02, Desember 2021 E-ISSN: 2655-7479 
mengintegrasikan sistem pembelajaran tatap muka dengan pembelajaran daring sebagai sarana pendukung yang diimplementasikan dalam sistem pendidikan di Indonesia; (2) Rekonstruksi peraturan perundang-undangan pada sistem pendidikan di Indonesia melalui metode Cognate Bills dengan mengakomodasi konsep pembelajaran hibrida dapat menjadi solusi yang progresif dalam transformasi pendidikan yang berkelanjutan. Maka, dengan menekankan dan mengaktualisasikan upaya digitalisasi pada sektor pendidikan diharapkan mampu meningkatkan kualitas pendidikan di Indonesia.

Kata Kunci: Cognate Bills; Pembelajaran Hibrida; Rekonstruksi Hukum

\section{Pendahuluan}

Kualitas pendidikan di Indonesia melalui hasil studi Programme for International Student Assessment (PISA) yang diselenggarakan oleh Organization for Economic Co-operation and Development (OECD), sejak tahun 2000 masih berada dibawah standar internasional OECD. Berdasarkan Gambar 1., yang menunjukkan hasil studi terbaru penilaian PISA pada tahun 2018, bahwa siswa di Indonesia masih mendapat nilai lebih rendah dari rata-rata negara di dunia yang berpartisipasi dalam penilaian ini. Hasil studi PISA ini menempati Indonesia dengan urutan ke72 dari 79 negara dalam hal literasi membaca, matematika, dan sains (Schleicher, 2018, hlm 6-8). Apabila melihat dari perspektif yang lebih luas, Indonesia telah melakukan langkah besar dengan cara meningkatkan tingkat partisipasi pendidikan. Pada tahun 2001, tingkat partisipasi pendidikan hanya mencakup $46 \%$ anak berusia 15 tahun di Indonesia; sementara pada tahun 2018, meningkat menjadi 85\% (OECD, 2018, hlm.3).

Gambar 1.

Tren Kinerja dalam Membaca, Matematika, dan Sains di Indonesia berdasarkan PISA

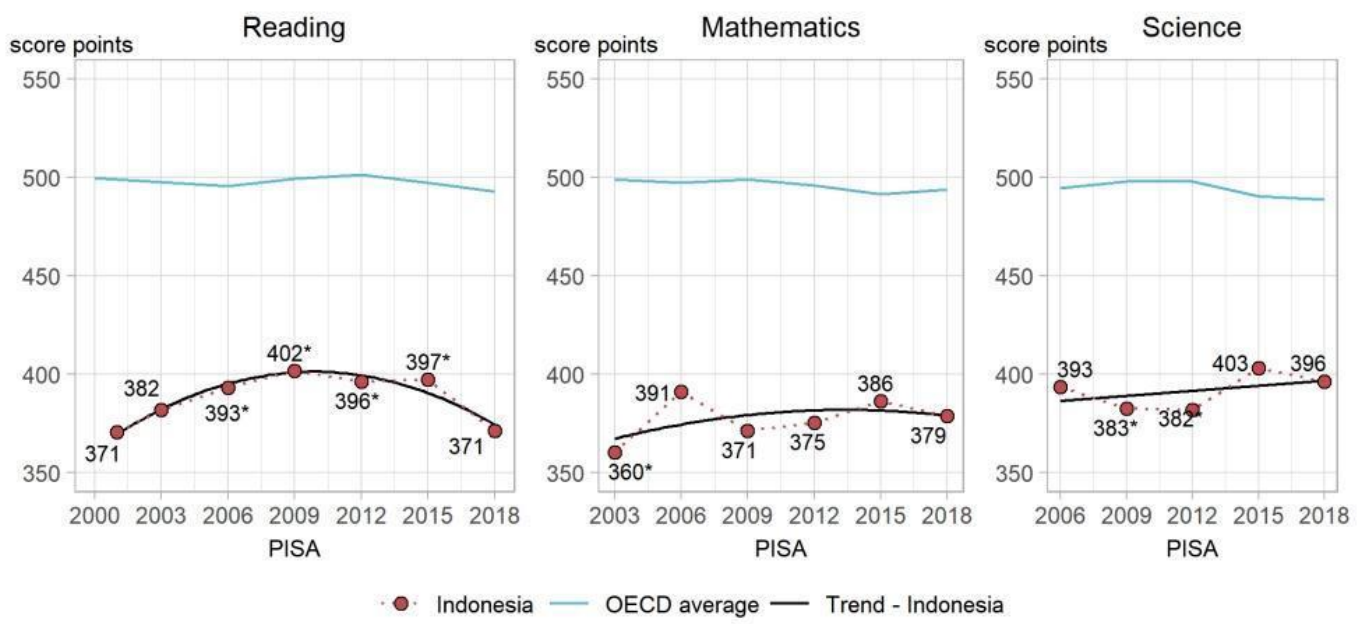

Sumber: Publikasi Organisation for Economic Co-operation and Development (OECD)

Peningkatan angka partisipasi pendidikan yang telah dilakukan Indonesia, sejalan dengan amanat konstitusi pada Pasal 31 Ayat (1) Undang-Undang Dasar Negara Republik Indonesia (UUD NRI) Tahun 1945 yang menyebutkan bahwa "Setiap warga negara berhak mendapatkan pendidikan" (UUD NRI, 1945, Pasal 31 Ayat (1)). Akan tetapi, meningkatkan angka partisipasi pendidikan juga harus diiringi dengan perbaikan dan peningkatan standar kualitas sistem pendidikan. Jika tidak diiringi dengan hal tersebut, maka dikhawatirkan siswa yang sebelumnya 
Jurnal Yustika

Vol. 24 No. 02, Des 2021

Halaman | 105

Digitalisasi Sistem

Pendidikan Dengan

Menerapkan

Pembelajaran

Hibrida Melalui

Rekonstruksi

Hukum

Menggunakan

Metode Cognate

Bills

Candya Upavata Kutey

Karta Negara, Daeli

Subrianty, Kamelia Desi

Awaliah

tidak mendapatkan akses pendidikan, akan menurunkan kinerja rata-rata dan distribusi kinerja kualitas pendidikan di Indonesia (OECD, 2018, hlm.3). Sehingga perlu dilakukan perbaikan dan peningkatan kualitas sistem pendidikan di Indonesia agar sesuai dengan level standar pendidikan internasional atau berada pada kebutuhan pasar global.

Pembelajaran Jarak Jauh (PJJ) adalah suatu sistem pembelajaran yang menggunakan berbagai sumber media belajar melalui teknologi informasi dan komunikasi, untuk memberikan akses pendidikan kepada kelompok masyarakat yang tidak berkesempatan mendapatkannya (UU SISDIKNAS, 2003). Konsep Pendidikan Jarak Jauh melalui media daring sebenarnya sudah diakomodasi dalam suatu peraturan perundang-undangan sektor pendidikan di Indonesia. Akan tetapi, pembelajaran daring tersebut masih terbatas pada beberapa perguruan tinggi yang melaksanakannya. Namun, menurut Direktur Jenderal Pendidikan Tinggi, Prof. Nizam, mengatakan bahwa pandemi Covid-19 berimplikasi pada transformasi digital di bidang pendidikan tinggi, yaitu lebih dari 4.000 institusi pendidikan tinggi di Indonesia beralih ke metode PJJ (Dikti Kemdikbud, 2020). Selain itu, banyaknya seminar atau webinar yang dilakukan secara virtual mengindikasikan bahwa aktivitas akademik tidak terhenti akibat adanya pandemi ini. Dengan demikian, pandemi Covid-19 memberikan suatu perubahan paradigma terhadap dunia akademik, yaitu dengan mendorong adanya transformasi digital pada sektor pendidikan.

Perubahan paradigma pada sektor pendidikan akibat pandemi Covid-19 dan dengan adanya perkembangan era digital di Indonesia mengakibatkan terjadinya peningkatan penggunaan akses internet pada siswa dengan rentang usia 5-24 tahun selama kurun waktu dua tahun terakhir (Avenzora et al., 2020). Hal ini sebagaimana juga termasuk ke dalam salah satu program Nawacita Presiden Joko Widodo yaitu Rencana Pembangunan Jangka Menengah Nasional (RPJMN) 2020-2024, dengan melakukan pembangunan pendidikan yang memanfaatkan perkembangan teknologi digital seiring dengan berkembangnya revolusi industri 4.0. Akan tetapi, perkembangan teknologi di Indonesia masih tidak merata, yaitu akses teknologi pada masyarakat perkotaan lebih baik dibanding daerah pedesaan. Hal tersebut dibuktikan dengan data dari BPS, yang menunjukkan persentase penggunaan internet pada siswa usia 5-24 tahun di daerah perkotaan sebesar $68,23 \%$, dibanding dengan daerah pedesaan sebesar 47,76\% (Avenzora et al., 2020). Maka, dapat diasumsikan bahwa pembelajaran full daring yang dilakukan selama pandemi Covid-19 belum efektif dan optimal untuk menjangkau seluruh penduduk di Indonesia.

Salah satu hal yang dapat menjadi solusi atas hal tersebut dan diharapkan mampu menjadi titik tumpu peningkatan kualitas pendidikan di Indonesia adalah dengan penerapan pembelajaran hibrida (hybrid learning) dalam sistem pendidikan. Menurut Ali Massoud, pembelajaran hibrida adalah sistem pembelajaran campuran yang merupakan perluasan dari sistem pembelajaran tatap muka (sinkron) dengan menambahkan pembelajaran berbasis internet (asinkron), yang tujuan utamanya adalah memajukan pengalaman belajar (Ali Massoud et al., 2011, hlm.4). Pembelajaran hibrida yang mengintegrasikan pembelajaran tatap muka dengan pembelajaran daring diharapkan mampu untuk menjangkau masyarakat yang kurang mendapat akses teknologi, Pada dasarnya, payung hukum untuk penerapan sistem pembelajaran hibrida ini telah diatur dalam Surat Keputusan Bersama Empat Menteri tentang Panduan Penyelenggaraan Pembelajaran di Masa Pandemi Coronavirus Disease 2019 (Covid-19). Namun, peraturan setingkat undang-undang pada sektor pendidikan belum memuat nomenklatur pembelajaran hibrida. Maka, untuk penerapan sistem pembelajaran hibrida yang berkelanjutan 
sebagai suatu transformasi di sektor pendidikan, diperlukan adanya peregulasian setara undangundang untuk mengaturnya.

Jurnal Yustika

Regulasi terkait bidang pendidikan di Indonesia secara garis besar diatur dalam UndangUndang Nomor 20 Tahun 2003 tentang Sistem Pendidikan Nasional (UU Sisdiknas). Namun secara khusus untuk bidang pendidikan tinggi diatur dalam Undang-Undang Nomor 12 Tahun 2012 tentang Pendidikan Tinggi (UU Dikti) dan mengenai pengajar diatur dalam UndangUndang Nomor 14 Tahun 2005 tentang Guru dan Dosen (UU GD). Permasalahan dalam regulasi di bidang pendidikan saat ini ialah adanya disharmonisasi, baik itu materi muatan maupun pengimplementasian undang-undangnya, antara satu regulasi dengan yang lain (Samsul, 2021). Salah satu contohnya adalah ketidakserasian ketentuan Pasal 37 ayat (2) UU Sisdiknas dan Pasal 35 UU Dikti mengenai kurikulum wajib pendidikan tinggi (Masnun \& Pratama, 2020, hlm. 10). Adanya suatu disharmonisasi akan memberikan dampak pada keberlangsungan kekeliruan atau ketidakefektifan pelaksanaan muatan undang-undang dan disfungsi hukum. Selain itu, kemajuan teknologi dan adanya pembaharuan dalam sistem pendidikan juga menjadi masalah utama dalam regulasi pendidikan. Sehingga diperlukan suatu rekonstruksi hukum terkait peraturan perundang-undangan di bidang pendidikan agar tidak terjadi tumpang tindih regulasi dan sesuai dengan kemajuan zaman.

Komisi X Dewan Perwakilan Rakyat Republik Indonesia (DPR RI) merencanakan untuk melakukan sinkronisasi peraturan perundang-undangan pada sektor pendidikan melalui revisi UU Sisdiknas dengan menggunakan metode omnibus law (Setjen DPR RI, 2021). Di berbagai negara, proses simplifikasi dan efisiensi dengan metode omnibus law mengakibatkan luasnya cakupan topik (multi and diverse subject) rancangan undang-undang yang berimplikasi pada penyelundupan pasal dan keterbatasan untuk mengkaji substansi pasal-pasal yang dapat mempersempit partisipasi publik (Juwana et al.,2020, hlm.26-27). Metode Cognate Bills dapat menjadi solusi alternatif proses legislasi sebagai upaya rekonstruksi hukum di sektor pendidikan dengan mengajukan rancangan revisi undang-undang yang saling berkaitan subjeknya menjadi satu paket yang dibahas bersamaan, tetapi tetap berbentuk beberapa rancangan yang terpisah. Dengan demikian, proses legislasi dengan metode Cognate Bills dapat menjadi solusi atas rekonstruksi hukum pada sektor pendidikan sebagai upaya untuk meningkatkan kualitas pendidikan di Indonesia.

Berdasarkan pemaparan latar belakang di atas, dapat ditarik suatu rumusan masalah, yaitu untuk mengetahui bagaimana penerapan konsep pembelajaran hibrida sebagai transformasi digital pendidikan yang berkelanjutan di Indonesia serta bagaimana rekonstruksi hukum di bidang pendidikan Indonesia melalui metode Cognate Bills dalam rangka pemberlakuan pembelajaran hibrida di Indonesia.
Vol. 24 No. 02, Des 202

Halaman | 106

Digitalisasi Sistem

Pendidikan Dengan Menerapkan

Pembelajaran

Hibrida Melalui

Rekonstruksi

Hukum

Menggunakan

Metode Cognate

Bills

Candya Upavata Kutey

Karta Negara, Daeli

Subrianty, Kamelia Desi

Awaliah 


\section{Metode Penelitian}

Jurnal Yustika

Vol. 24 No. 02, Des 2021

Halaman | 107

Digitalisasi Sistem

Pendidikan Dengan

Menerapkan

Pembelajaran

Hibrida Melalui

Rekonstruksi

Hukum

Menggunakan

Metode Cognate

Bills

Candya Upavata Kutey

Karta Negara, Daeli

Subrianty, Kamelia Desi

Awaliah

Jenis penelitian ini termasuk kedalam penelitian hukum normatif dengan studi kepustakaan terhadap bahan hukum primer, yaitu peraturan perundang-undangan dan bahan hukum sekunder, yaitu literatur yang terkait topik pembelajaran hibrida dan pengaturan hukumnya, serta bahan hukum tersier sebagai bahan pendukung. Adapun bahan hukum primer berupa peraturan perundang-undangan yang digunakan adalah Undang-Undang Dasar Negara Republik Indonesia (UUD NRI) Tahun 1945; Undang-Undang Nomor 20 Tahun 2003 tentang Sistem Pendidikan Nasional; Undang-Undang Nomor 12 Tahun 2012 tentang Pendidikan Tinggi; Undang-Undang Nomor 14 Tahun 2005 tentang Guru dan Dosen; Undang-Undang Nomor 11 Tahun 2020 tentang Cipta Kerja; dan Peraturan Pemerintah Nomor 48 Tahun 2005 tentang Pengangkatan Pegawai Negeri Sipil. Selain itu, penelitian ini dilandaskan oleh teori hukum pembangunan dari Mochtar Kusumaatmadja sebagai bahan hukum sekunder. Pendekatan dalam penelitian ini adalah Statute approach, Conceptual approach, dan Analytical Approach yang digunakan untuk membahas dan menelaah bahan-bahan hukum guna merancang suatu ius constituendum terkait dengan penerapan pembelajaran hibrida sebagai upaya digitalisasi pada sistem pendidikan di Indonesia.

\section{Pembahasan}

\subsection{Konsep Penerapan Pembelajaran Hibrida Sebagai Transformasi Digital Pendidikan yang Berkelanjutan di Indonesia}

Pendidikan merupakan salah satu sektor yang paling krusial dalam proses perkembangan suatu bangsa serta merupakan salah satu isu yang paling disoroti dunia, seperti dalam tujuan ke empat Sustainable Development Goals (SDGs) atau Tujuan Pembangunan Berkelanjutan, yaitu untuk tercapainya peningkatan kesempatan belajar bagi seluruh elemen masyarakat dan untuk menjamin adanya inklusi pendidikan yang berkualitas. SDGs sendiri merupakan agenda pembangunan berkelanjutan yang diresmikan oleh para pemimpin negara di Perserikatan Bangsa-Bangsa (PBB) pada 25 September 2015 dengan tujuan untuk mengatasi masalah lingkungan, kemiskinan, dan kesenjangan di dunia (SDG 2030 Indonesia, 2017). Pendidikan bukan hanya sekedar tentang menciptakan para penerus bangsa saja tetapi juga tentang menyiapkan masa depan yang dapat mensejahterakan manusia. Oleh karena itu, tingkat kualitas pendidikan suatu bangsa haruslah mencapai tingkat yang tinggi dan memenuhi semua standar suatu pendidikan yang baik sesuai perkembangan zaman.

Masih rendahnya kualitas pendidikan di Indonesia membuat pemerintah harus lebih baik lagi dalam memutuskan suatu kebijakan dan menerapkan sistem pembelajaran. Perubahan sistem pembelajaran yang pada mulanya berbasis luring tatap muka, yang kemudian menjadi pembelajaran daring akibat adanya pandemi Covid-19 memberikan dampak yang signifikan bagi pendidikan Indonesia. Dengan memanfaatkan penggunaan teknologi, PJJ yang telah berjalan selama lebih dari satu tahun ini memiliki beberapa kekurangan yang dirasa belum mampu menjadi solusi untuk meningkatkan kualitas pendidikan contohnya yaitu kurangnya motivasi atau inisiatif ketika proses pembelajaran, tidak adanya sarana pendukung seperti jaringan dan ponsel, dan kurang efektifnya pembelajaran tanpa interaksi langsung (Mustafa, 2020). Kekurangan tersebut sebenarnya dapat diatasi dengan menerapkan sistem pembelajaran hibrida. Pembelajaran hibrida dapat memfasilitasi penyampaian pendidikan dalam konteks 
modern yang memanfaatkan teknologi informasi, sambil berfokus pada pencapaian tujuan pembelajaran (Maurice E. et al., 2021).

\subsubsection{Konsep Pembelajaran Hibrida}

Sistem pembelajaran hibrida merupakan suatu pembelajaran dengan menggabungkan instruksi pengajaran langsung dan instruksi pengajaran jarak jauh. Instruksi pengajaran jarak jauh dilakukan karena pengajar dan peserta didik terpisah secara fisik. Konsep pembelajaran hibrida yang dimaksud adalah penggabungan secara simultan antara kedua instruksi pengajaran tersebut, yaitu sebagian peserta didik secara fisik hadir dalam kelas, sementara peserta didik lain bergabung dengan berbagai platform teknologi yang tersedia seperti aplikasi konferensi. Hal ini dapat memungkinkan adanya partisipasi peserta didik dari mana saja dengan menghilangkan batas-batas geografis, yang mengarah kepada fleksibilitas dan terciptanya inklusi pendidikan.

Pembelajaran hibrida juga dapat didukung secara asinkron dengan memberikan konsep pengajaran yang diberikan oleh pengajar kepada peserta didik, yang kemudian ditindaklanjuti dengan aktivitas pembelajaran daring melalui media teknologi yang mendukung, yang kemudian diberikan umpan balik berupa penilaian maupun koreksi dari pengajar. Media teknologi asinkron yang dapat mendukung pembelajaran hibrida, yaitu antara lain: Blackboard, Edmodo, dan Moodle, yang merupakan sistem manajemen pembelajaran virtual umum yang banyak diadopsi oleh institusi pendidikan (Alokluk, 2018)

Tujuan dilaksanakannya pembelajaran hibrida adalah untuk memberikan sebuah lingkungan belajar yang fleksibel dan nyaman agar mampu meningkatkan minat pembelajaran dan interaksi sosial sehingga kegiatan tersebut efektif dan efisien. Menurut pendapat Fauzan dan Arifin, konsep pembelajaran hibrida memiliki beberapa kelebihan, yaitu: (1) memberikan kemudahan bagi pengajar dalam menyampaikan materi pembelajaran karena materi tersebut diunggah ke sistem e-learning, sehingga siswa pun dapat dengan mudah mengakses materi pembelajaran karena bisa diunduh kapan saja; (2) sistem e-learning juga dapat menghemat waktu pembelajaran sebab melakukan absensi, pelacakan perkembangan belajar, dan administrasi nilai secara otomatis (Fauzan dan Arifin, 2017, hlm. 250-252).

Menurut Driscoll (2002, hlm. 1) terdapat empat konsep terkait pembelajaran hibrida, yaitu, pertama, pembelajaran yang mengkombinasikan beberapa teknologi informasi dan komunikasi seperti website sebagai sarana pendukung dari tujuan pendidikan, seperti pengajaran melalui meeting conference, self learning, pembelajaran kooperatif, streaming video, audio, dan materi pembelajaran berbasis digital teks. Kedua, kombinasi dari berbagai pedagogi atau ilmu pengajaran, misalnya konstruktivisme, behaviorisme, dan kognitivisme, agar dapat mengoptimalkan capaian pembelajaran. Ketiga, kombinasi dari bentuk teknologi pembelajaran instruksional, seperti video tape, CD-ROM, web-based training, dan film dengan pembelajaran tatap muka. Dan keempat, kombinasi dari teknologi pembelajaran dengan tugas pekerjaan yang sebenarnya agar keharmonisan kegiatan pembelajaran dan bekerja dapat tercipta. Intinya adalah bahwa pembelajaran hibrida berarti berbeda bagi orang yang berbeda, tergantung penggambaran potensinya yang belum dimanfaatkan secara luas.
Jurnal Yustika Vol. 24 No. 02, Des 2021

Halaman | 108 Digitalisasi Sistem Pendidikan Dengan Menerapkan Pembelajaran Hibrida Melalui Rekonstruksi Hukum Menggunakan Metode Cognate Bills

Candya Upavata Kutey Karta Negara, Daeli Subrianty, Kamelia Desi Awaliah 
Jurnal Yustika

Vol. 24 No. 02, Des 2021

Halaman | 109

Digitalisasi Sistem

Pendidikan Dengan

Menerapkan

Pembelajaran

Hibrida Melalui

Rekonstruksi

Hukum

Menggunakan

Metode Cognate

Bills

Candya Upavata Kutey

Karta Negara, Daeli

Subrianty, Kamelia Desi

Awaliah
Penerapan sistem pembelajaran hibrida secara efektif mampu meningkatkan mutu pembelajaran, dengan adanya peningkatan rata-rata hasil belajar siswa (Rahmatillah, 2013). Hal ini juga sesuai dengan penelitian Sarah Bibi, yang menyatakan bahwa pembelajaran hibrida atau blended learning mampu meningkatkan motivasi belajar dan tingkat pemahaman mahasiswa (Bibi, 2015). Peningkatan tersebut dapat terjadi karena selain adanya interaksi langsung dengan pembelajaran tatap muka, mahasiswa juga dapat mengakses materi yang diberikan secara daring di mana saja. Namun keberhasilan dari sistem pembelajaran hibrida ini tidak dapat terjadi secara otomatis, beberapa faktor yang paling mempengaruhinya adalah pertimbangan pedagogi dan desain instruksional mengenai pemanfaatan alat-alat teknologi, pemfasilitasan interaksi, pemberian motivasi, serta pengaturan terkait pemberian materi pembelajaran yang lebih baik secara daring.

Penerapan pembelajaran hibrida di masa depan memiliki potensi yang luar biasa karena beberapa faktor. Pertama, pengalaman saat ini telah terbukti berhasil dalam memberikan instruksi di bawah lingkungan yang menantang. Pendidikan jarak jauh pada masa pandemi Covid-19 ini dapat memfasilitasi sarana pembelajaran. Kedua, perkembangan teknologi meningkat secara signifikan yang dapat menjadi sarana pendukung pada pembelajaran hibrida. Teknologi tersebut termasuk platform konferensi video, lab virtual, dan platform untuk mengakses materi dan memberikan tugas secara online. Selain itu, meningkatnya persaingan di antara perusahaan sebagai developer yang dapat memproduksi teknologi, menunjukkan bahwa akan ada berbagai alat yang terjangkau untuk mendukung pembelajaran hibrida. Ketiga, pembelajaran hibrida telah disukai oleh generasi saat ini. Dengan demikian, peserta didik akan lebih mau dan siap untuk mengadopsinya di masa depan. Selain itu, wali dan orang tua menjadi lebih ramah menuju pembelajaran jarak jauh. Mereka juga memperoleh berbagai keterampilan dari interaksi mereka dengan adanya pembelajaran jarak jauh. Dengan demikian, mereka akan lebih menerima dan mendukung pembelajaran jarak jauh. Cendekiawan dan stakeholder di sektor ini juga telah menunjukkan minat untuk menyelidiki pembelajaran hibrida sebagai pembelajaran yang efektif melalui media untuk menyampaikan pendidikan di masa depan. Akibatnya, ada banyak bahan ilmiah dan informasi untuk mendukung implementasi di masa depan. Selanjutnya, konten pendidikan akan menjadi lebih interaktif untuk memungkinkan peserta didik melakukan eksperimen praktis secara individu dan kolektif sambil memberikan hasil instan. Terakhir, kemajuan yang dibuat dalam Artificial Intelligence (AI) akan bermanfaat untuk pembelajaran hibrida. AI akan membantu memenuhi kebutuhan individu siswa melalui pembelajaran mesin yang melacak aktivitas siswa dan kemajuan untuk menghasilkan wawasan berharga ke dalam hasil belajar mereka. Dengan demikian, pembelajaran hibrida memiliki prospek yang menjanjikan masa depan sebagai media penyampaian pendidikan (Maurice et al., 2021).

\subsubsection{Tantangan dan Hambatan Penerapan Pembelajaran Hibrida}

\subsubsection{Kesenjangan Akses Teknologi}

Pembelajaran hibrida yang mengintegrasikan instruksi pembelajaran tatap muka dengan instruksi pembelajaran daring tentunya membutuhkan sarana berupa media telekomunikasi dan informasi yang memadai untuk 
mendukung pembelajaran hibrida yang berkelanjutan. Di Indonesia sendiri masih terdapat kesenjangan dalam akses perkembangan teknologi (Henri, 2013). Hal ini dapat dilihat dari masyarakat perkotaan yang mendapatkan akses teknologi yang lebih baik dibanding masyarakat pedesaan. Selain itu, selama pandemi Covid-19 yang memaksa sektor pendidikan untuk melakukan pembelajaran full daring, terdapat keterbatasan sumber daya dalam hal pemanfaatan teknologi pendidikan seperti akses internet dan kuota yang memperjelas kesenjangan akses teknologi antara sekolah besar di perkotaan dengan sekolah di daerah (Pusdatin Kemdikbud, 2020).

Tabel 1.

Persentase Akses Teknologi Informasi dan Komunikasi Pada Siswa Usia 5-24 Tahun Selama Tahun 2020

\begin{tabular}{|c|c|c|c|}
\hline \multirow[b]{2}{*}{ Karakteristik } & \multicolumn{3}{|c|}{ Akses Teknologi Informasi dan Komunikasi } \\
\hline & $\begin{array}{l}\text { Menggunakan } \\
\text { Telepon Seluler }\end{array}$ & $\begin{array}{l}\text { Menggunakan } \\
\text { Komputer }\end{array}$ & $\begin{array}{c}\text { Menggunakan } \\
\text { Intemet }\end{array}$ \\
\hline Total & 77,12 & 24,11 & 59,33 \\
\hline \multicolumn{4}{|l|}{ Tipe Daerah } \\
\hline Perkotaan & 81,30 & 30,79 & 68,23 \\
\hline Pedesaan & 71,70 & 15,44 & 47,76 \\
\hline \multicolumn{4}{|l|}{ Jenjang Pendidikan } \\
\hline $\mathrm{SD} /$ Sederajat & $6,3,29$ & 6,68 & 35,97 \\
\hline SMP/Sederajat & 85,97 & 28,60 & 73,40 \\
\hline SMA/Sederajat & 95,49 & 45,78 & 91,01 \\
\hline Penguruan Tinggi & 98,06 & 68,15 & 95,30 \\
\hline
\end{tabular}

Sumber: Badan Pusat Statistik, Susenas Maret 2020

Berdasarkan tabel di atas, terlihat bahwa persentase total siswa usia 5-24 tahun yang menggunakan telepon seluler sebesar 77,12\%; siswa yang menggunakan komputer sebesar $24,11 \%$; dan menggunakan internet sebesar 59\%. Sementara itu, berdasarkan tipe daerah, penggunaan telepon seluler pada siswa di perkotaan lebih tinggi dibanding siswa di pedesaan (81,30\% berbanding $71,70 \%)$; Sama halnya dengan penggunaan komputer/PC dengan persentase siswa di perkotaan yang menggunakan komputer/PC dua kali lipat lebih tinggi dari siswa di pedesaan (30,79\% berbanding 15,44\%); Begitu pun dengan penggunaan internet siswa di perkotaan lebih tinggi dibanding dengan pedesaan $(68,23 \%$ berbanding $47,76 \%)$. Jika ditinjau berdasarkan tingkat pendidikan, pemakaian telepon seluler, komputer/PC, dan internet pada SD/sederajat yang masih dibawah dibanding dengan jenjang pendidikan lainnya, persentase penggunaan telepon seluler, komputer/PC, dan internet naik seiring meningkatnya jenjang pendidikan yang lebih tinggi.

Kementerian Komunikasi dan Informatika (KOMINFO) di masa pandemi ini telah berkomitmen untuk membangun infrastruktur digital yang kuat dan inklusif untuk mempercepat transformasi digital. Hal ini dapat untuk mengatasi masalah kesenjangan terhadap akses teknologi 
Jurnal Yustika

Vol. 24 No. 02, Des 2021

Halaman | 111 Digitalisasi Sistem Pendidikan Dengan Menerapkan Pembelajaran Hibrida Melalui Rekonstruksi Hukum Menggunakan Metode Cognate Bills

Candya Upavata Kutey Karta Negara, Daeli Subrianty, Kamelia Desi Awaliah yang menjadi tantangan bagi pemberlakuan pembelajaran hibrida yang berkelanjutan. Pembangunan infrastruktur tersebut dilakukan melalui peningkatan konektivitas menggunakan kabel serat optik dan peluncuran High-Throughput Satelit SATRIA-1 pada kuartal ketiga tahun 2023 yang dapat menyediakan akses internet di 150.000 titik akses publik dari total 501.000 titik akses publik yang ada di Indonesia dengan kapasitas total 150 Gbps (Biro Humas Kominfo, 2021). Dari 150.000 titik akses publik, 93.900 titik digunakan untuk mendukung akses pada sektor pendidikan.

\subsubsection{Penciptaan Iklim Pembelajaran yang Efektif}

Terdapat beberapa kritik terkait dengan efektivitas pembelajaran hibrida, terutama berkaitan dengan aspek pembelajaran jarak jauh. Salah satunya adalah pembelajaran hibrida dapat berpotensi mengakibatkan hilangnya interaksi antara pengajar dengan siswa. Pembatasan interaksi fisik antara pengajar dan siswa tersebut dapat mengakibatkan gangguan perkembangan sosial pada siswa yang berimplikasi pada menurunnya efektivitas iklim pembelajaran (Raes et al., 2020). Hal ini karena iklim pembelajaran yang baik harus dapat mengembangkan keterampilan kognitif dan sosial secara beriringan. Tantangan utama lainnya adalah pada beberapa disiplin ilmu, seperti sains, yang melibatkan kombinasi instruksi lisan dan kegiatan langsung yang dimaksudkan untuk menanamkan pengetahuan dan keterampilan praktis, dapat mengganggu peserta didik dari aspek sesi praktikal yang dibutuhkan. Selain itu, pembelajaran hibrida rentan terhadap permasalahan teknis seperti kesalahan jaringan dan downtime.

Dibutuhkan kerjasama dari berbagai stakeholder untuk mengatasi tantangan dan hambatan pembelajaran hibrida yang berkelanjutan. Stakeholder khususnya di bidang pendidikan harus mengadopsi pedagogi, andragogi, dan heutagogi yang tepat untuk menerapkan pembelajaran hibrida. Seperti, pada prinsipnya pengajar harus menerapkan pembelajaran yang tidak hanya pemberian materi pelajaran secara dogmatis dan satu arah, melainkan harus interaktif yang melibatkan diskusi kelompok. Selain itu, lembaga pendidikan juga harus menyediakan media pembelajaran daring pendukung yang memiliki userfriendly interface yang efisien dengan menyesuaikan tingkat dan kebutuhan siswa. Selain itu, untuk mengatasi tantangan jarak dan logistik adalah dengan mengalokasikan waktu yang tepat akan memungkinkan peserta didik untuk berpartisipasi secara memuaskan dalam sesi praktik dan memenuhi hasil belajar meskipun menerima beberapa instruksi mereka secara daring, serta lembaga pendidikan terkait diupayakan untuk menyediakan pusat pembelajaran tambahan bagi pelajar jarak jauh untuk melakukan sesi praktis (Hwang, 2018). Dengan demikian, berbagai pendekatan yang telah disebutkan sebelumnya, diharapkan mampu untuk menjadi solusi atas tantangan penerapan pembelajaran yang berkelanjutan. 


\subsubsection{Permasalahan Regulasi Sektor Pendidikan}

Pembukaan UUD NRI 1945 salah satunya mengamanatkan pemerintah Indonesia untuk mencerdaskan kehidupan bangsa. Maka pemerintah pada masa orde baru membentuk Undang-Undang Nomor 2 Tahun 1989 tentang Sistem Pendidikan Nasional, yang kemudian disempurnakan menjadi Undang-Undang Nomor 20 Tahun 2003 tentang Sistem Pendidikan Nasional (UU Sisdiknas). Undang-undang tersebut mengatur sistem pendidikan secara umum, yang membutuhkan peraturan pelaksana secara teknis dan khusus untuk mengimplementasikannya. Namun, beberapa topik turunan diatur terpisah pada peraturan setingkat undang-undang, antara lain Undang-Undang Guru dan Dosen yang mengatur tentang definisi dan kualifikasi dari tenaga pengajar pendidikan dasar dan menengah formal, serta Undang-Undang Pendidikan Tinggi yang mengatur tentang penyelenggaraan dan pengelolaan perguruan tinggi (Argama, 2020).

Adanya beberapa topik turunan UU Sisdiknas dan peraturan undang-undang yang berkaitan dengan pendidikan berimplikasi pada disharmonisasi hukum berupa adanya peraturan perundang-undangan yang beririsan dengan UU Sisdiknas. Salah satunya seperti UU Pendidikan Tinggi, yang dari segi muatan bertentangan dengan UU Sisdiknas yang mengamanatkan penyelenggaraan pendidikan tinggi diatur lebih lanjut dengan peraturan pemerintah (UU Sisdiknas, 2003, Pasal 24 Ayat (4)). Selain itu, pada Undang-Undang Nomor 11 Tahun 2020 tentang Cipta Kerja (UU Ciptaker) yang menggunakan metode omnibus law, terdapat penyelundupan pasal tentang pendidikan. Meskipun sebelumnya materi muatan tentang sektor pendidikan telah dikeluarkan dari draft RUU Ciptaker setelah mendapat banyak kritik (Hidayat, 2020). Pasal yang dimaksud adalah pada Pasal 65 Paragraf 12.

Pasal 65 Paragraf 12 UU Ciptaker, yang pada ayat (1) dan (2) berbunyi, "Pelaksanaan perizinan pada sektor pendidikan dapat dilakukan melalui Perizinan Berusaha sebagaimana dimaksud dalam Undang-Undang ini. Dan ketentuan lebih lanjut pelaksanaan perizinan pada sektor pendidikan sebagaimana dimaksud pada ayat (1) diatur dalam Peraturan Pemerintah." Ketentuan tersebut memungkinkan adanya mekanisme perizinan berusaha pada sektor pendidikan, yang menyebabkan penyelenggaraan pendidikan mengarah kepada komersialisasi. Hal ini berpotensi terjadinya peningkatan biaya pendidikan. Biaya pendidikan yang buruk adalah salah satu indikator yang menyebabkan kualitas pendidikan di Indonesia mengalami stagnasi dan tidak kunjung membaik (Rosser, 2018). Pasal 65 hanya wajib berlaku bagi lembaga pendidikan formal pada Kawasan Ekonomi Khusus (KEK), yang berarti institusi pendidikan sebagai pihak penyelenggara dan pengelola di kawasan KEK harus melewati mekanisme perizinan berusaha yang ada pada UU Ciptaker. Sementara itu, institusi pendidikan formal yang tidak berada pada kawasan KEK, tetap mengikuti ketentuan peraturan yang sudah ada sebelumnya, yang ada pada UU Sisdiknas, UU Pendidikan Tinggi, UU Guru, dan Dosen, UU Pendidikan Kedokteran, dan UU Pesantren (UU Ciptaker, 2020, Penjelasan Pasal 65). Selain itu, pada penjelasan Pasal 65 tersebut juga terdapat ketentuan bahwa lembaga pendidikan formal di luar kawasan KEK, secara sukarela dapat mengikuti mekanisme perizinan berusaha yang ada pada UU Ciptaker.

Pasal 65 UU Ciptaker tersebut juga akan berpotensi munculnya kesenjangan kualitas pendidikan dengan adanya mekanisme perizinan berusaha pada lembaga pendidikan formal kawasan KEK, yang dapat berpeluang menjalin kerja sama 
Jurnal Yustika

Vol. 24 No. 02, Des 2021

Halaman | 113

Digitalisasi Sistem

Pendidikan Dengan

Menerapkan

Pembelajaran

Hibrida Melalui

Rekonstruksi

Hukum

Menggunakan

Metode Cognate

Bills

Candya Upavata Kutey

Karta Negara, Daeli

Subrianty, Kamelia Desi

Awaliah dengan pihak investor untuk meningkatkan kualitas pendidikan, dengan feedback berupa penarikan biaya pendidikan yang tinggi. Sementara lembaga pendidikan formal di luar kawasan KEK yang tidak menerapkan mekanisme perizinan berusaha, hanya mendasarkan penyelenggaraan biaya melalui bantuan pemerintah atau sumber lain, yang menyebabkan kualitas pendidikan yang tidak akan sama dengan lembaga pendidikan formal yang ada di kawasan KEK. Hal ini bertentangan dengan konstitusi dan UU Sisdiknas yang mengamanatkan pemerintah untuk menyelenggarakan pendidikan secara demokratis, berkeadilan, dan tidak diskriminatif dengan menjunjung tinggi Hak Asasi Manusia (UU Sisdiknas, 2003, Pasal 4 Ayat (1)).

Putusan Mahkamah Konstitusi Nomor 91/PUU-XVIII/2020 menyatakan bahwa UU Ciptaker cacat secara formil dengan konsekuensi inkonstitusional bersyarat dengan tenggang waktu dua tahun apabila pembentuk undang-undang tidak dapat menyelesaikan perbaikan UU Ciptaker, maka ketentuan pada UU Ciptaker tidak dapat berlaku kembali. Salah satu muatan yang diajukan sebagai batu uji dalam pengujian formil pada putusan tersebut adalah Pasal 65 terkait dengan sektor pendidikan. Hal ini menegaskan adanya disharmonisasi hukum pada sektor pendidikan. Selain itu, menunjukkan bahwa penggunaan omnibus law sebagai proses legislasi dengan tujuan simplifikasi regulasi terdapat suatu ketidakpastian hukum yang ditimbulkan. Dengan demikian, dibutuhkan suatu metode proses legislasi yang dalam hal ini adalah untuk melakukan harmonisasi hukum pada sektor pendidikan.

Disharmonisasi lainnya adalah terkait dengan rekrutmen guru di daerah yang diatur pada Peraturan Pemerintah Nomor 48 Tahun 2005 tentang Pengangkatan Tenaga Honorer Menjadi Calon Pegawai Negeri Sipil (PP 48/2005), yang mengatur pemerintah daerah tidak dapat melakukan rekrutmen guru dengan skema tenaga honorer. Maka rekrutmen guru hanya dapat dilakukan melalui rekrutmen Aparatur Sipil Negara (ASN), dengan dasar alokasi anggaran pendidikan dalam APBN. Hal ini dapat menyebabkan tidak terpenuhinya kebutuhan guru di daerah dikarenakan perekrutan guru tidak didasarkan pada kebutuhan guru yang ada. Sistem rekrutmen guru yang terdapat pada PP 48/2005 tersebut bertentangan dengan UU Sisdiknas yang mengamanatkan bahwa pemerintah daerah harus mampu memastikan terfasilitasinya ketersediaan tenaga pendidik pada setiap satuan pendidikan di daerah masing-masing (UU Sisdiknas, 2003, Pasal 41 Ayat (3)).

Pasal 1 Ayat (3) UUD NRI 1945 menyebutkan bahwa Indonesia adalah negara hukum (rechtstaat). Hal tersebut berarti bahwa negara Indonesia menganut dan berlandaskan pada suatu tatanan hukum dalam mengatur kehidupan masyarakat dalam berbangsa dan bernegara. Menurut Hans Kelsen, keabsahan suatu norma hukum ditetapkan dan ditentukan oleh norma hukum lain, yang dengan demikian norma hukum yang lain itu merupakan dasar untuk keabsahan norma hukum baru. Selain itu, tatanan hukum bukanlah sistem norma saling terkoordinasi dan berkedudukan sama, melainkan memiliki hierarki sebuah norma hukum dengan berbagai jenjang (Kelsen, 1978). Konsistensi suatu peraturan perundang-undangan, bukan suatu hal yang terjadi dengan sendirinya, melainkan harus diciptakan (Slamet, 2014). Dengan demikian, suatu tatanan hukum seharusnya konsisten dan tidak bertentangan satu sama lain, dalam hal ini 
pemerintah sebagai penyelenggara negara harus memastikan suatu tatanan hukum berjalan harmonis dan konsisten.

\subsection{Rekonstruksi Hukum di Bidang Pendidikan Indonesia Melalui Metode Cognate} Bills

Sektor Pendidikan merupakan suatu bentuk usaha dalam mewujudkan proses pembelajaran yang efektif dan optimal, agar para peserta didik mampu mengembangkan potensi dirinya untuk memiliki kekuatan spiritual keagamaan, pengendalian diri, kepribadian, kecerdasan, akhlak mulia, serta keterampilan yang diperlukan dirinya, masyarakat, bangsa, dan negara. (UU Sisdiknas, 2003). Hal ini menunjukkan bahwa pendidikan merupakan fondasi yang penting dalam setiap proses pembentukan dan pengembangan potensi Sumber Daya Manusia (SDM) di Indonesia (Safitri et al., 2003). Dalam proses pembelajaran, metode penyampaian materi pembelajaran terbagi menjadi 2 (dua) yakni sistem pendidikan konvensional dengan cara tatap muka dan sistem pendidikan jarak jauh yang dilakukan secara daring. Selain kedua metode pembelajaran tersebut, terdapat juga sistem pembelajaran hibrida yang merupakan salah satu bentuk inovasi dari kemajuan teknologi di bidang pendidikan Indonesia.

Adapun pengaturan dari sistem pendidikan konvensional dan jarak jauh telah dimuat dalam UU Sisdiknas. Akan tetapi, payung hukum dari sistem pembelajaran hibrida belum diakomodasikan dalam peraturan setingkat undang-undang. Sistem pembelajaran hibrida hanyalah diatur dalam Surat Keputusan Bersama Empat Menteri tentang Panduan Penyelenggaraan Pembelajaran di Masa Pandemi Coronavirus Disease 2019 (Covid-19). Secara teoritis, kedudukan SKB dikategorikan sebagai suatu Keputusan (beschikking), walaupun materi muatan SKB tersebut lebih bersifat peraturan (regeling) (Yuliandri, 2019). Hal ini berarti bahwa SKB berkedudukan sebagai kekuatan hukum mengikat sesuai amanat dari ketentuan Pasal 8 ayat (2) Undang-Undang Nomor 12 Tahun 2011 tentang Pembentukan Peraturan PerundangUndangan. Nomenklatur SKB sebagaimana Keputusan Menteri, secara eksplisit memang tidak berada pada hierarki peraturan perundang-undangan, namun secara implisit format SKB diakui dan berkedudukan di antara Perpres dan Perda berdasarkan pada Pasal 8 Ayat (2) UU 12/2011. Hal ini menunjukkan bahwa format SKB yang digunakan untuk mengatur pemberlakuan pembelajaran hibrida berada di bawah UU Sisdiknas, yang mengakibatkan sistem pembelajaran hibrida belum terakomodasi dalam muatan peraturan perundang-undangan yang setingkat dengan undang-undang, sehingga dibutuhkan pemuatan substansi pembelajaran hibrida ke dalam peraturan perundang-undangan setingkat UU, untuk merealisasikan pembelajaran hibrida yang berkelanjutan sebagai upaya peningkatan inklusi pendidikan yang berkualitas.

Untuk menindaklanjuti pemuatan substansi pengaturan dari pembelajaran hibrida pada peraturan perundang-undangan setingkat undang-undang, dibutuhkan suatu rekonstruksi hukum pada sektor pendidikan. Selain itu, rekonstruksi hukum dilakukan sebagai upaya harmonisasi peraturan perundang-undangan di bidang pendidikan. Harmonisasi peraturan perundang-undangan diatur pada Pasal 47 Ayat (3) UU 12/2011. Harmonisasi hukum bertujuan untuk menyelaraskan dan menyesuaikan suatu rancangan undang-undang dengan peraturan perundang-undangan lain untuk mewujudkan tatanan hukum yang tersusun secara sistematis dan tidak saling bertentangan satu sama lain atau tumpang tindih (overlapping) (Soegiyono, 2015). Dengan demikian, selain untuk mengatasi permasalahan overlapping regulasi pada sektor pendidikan yang telah dijelaskan pada sub pembahasan sebelumnya, rekonstruksi hukum juga Vol. 24 No. 02, Des 202

Halaman | 114 Digitalisasi Sistem Pendidikan Dengan Menerapkan Pembelajaran Hibrida Melalui Rekonstruksi Hukum Menggunakan Metode Cognate Bills

Candya Upavata Kutey Karta Negara, Daeli Subrianty, Kamelia Desi Awaliah 
Jurnal Yustika

Vol. 24 No. 02, Des 2021

Halaman | 115

Digitalisasi Sistem

Pendidikan Dengan

Menerapkan

Pembelajaran

Hibrida Melalui

Rekonstruksi

Hukum

Menggunakan

Metode Cognate

Bills

Candya Upavata Kutey

Karta Negara, Daeli

Subrianty, Kamelia Desi

Awaliah

diperlukan untuk mengakomodasi legal standing pelaksanaan pembelajaran hibrida yang berkesinambungan.

Harmonisasi hukum yang dapat dilakukan dalam hal ini adalah dengan suatu rekonstruksi hukum pada sektor pendidikan. Definisi rekonstruksi menurut Black Law Dictionary adalah "reconstruction is the act or process of rebuilding, recreating, or reorganizing something"(Bryan A. Garner, 2018). Dalam hal ini dapat diinterpretasikan bahwa rekonstruksi hukum yang dimaksud adalah dengan suatu proses pembangunan kembali, menciptakan kembali, atau mereorganisasi kembali suatu tatanan hukum pada sektor pendidikan untuk dapat memaksimalkan potensi dari pembelajaran hibrida seiring dengan kemajuan teknologi. Mochtar Kusumaatmadja melalui gagasan teori hukum pembangunan yang beliau ciptakan, menyebutkan bahwa hukum adalah suatu sarana pembaharuan dan perubahan masyarakat yang didasarkan pada perubahan-perubahan sosial (social of change) atau rekayasa sosial (social engineering), serta disesuaikan dengan kebutuhan masyarakat secara kontemporer. Dengan kata lain, Hukum sebagai sarana pembaharuan masyarakat adalah bahwa hukum sebagai kaidah dapat berfungsi sebagai alat untuk mengatur pembangunan pada penyalur arah kegiatan masyarakat ke arah yang dikehendaki oleh pembaharuan (Kusumaatmadja, 1976). Dengan demikian, rekonstruksi hukum pada bidang pendidikan diperlukan sebagai bentuk rekayasa sosial untuk pembaharuan masyarakat dan peradaban.

Banyaknya peraturan perundang-undangan pada sektor pendidikan berimplikasi pada banyaknya biaya penyusunan dan pembahasan dan memerlukan waktu yang relatif lama. Maka, Komisi X DPR RI berencana untuk melakukan harmonisasi hukum pada sektor pendidikan menggunakan metode omnibus law untuk mempercepat proses legislasi (Setjen DPR RI, 2021). Namun, metode omnibus law juga memiliki kelemahan berupa luasnya cakupan topik (multi and diverse subject) yang berpotensi pada penyelundupan pasal, serta dapat mempersempit ruang partisipasi publik karena keterbatasan untuk mengkaji substansi pasal secara dalam akibat luasnya cakupan topik yang ada. Dengan demikian, sebagai upaya alternatif untuk melakukan rekonstruksi hukum, berdasarkan lembaga parlemen di Selandia Baru (The House), melalui Standing order pada tahun 2011, mengadopsi alternatif proses legislasi berupa Cognate Bills yang memiliki nilai transparansi yang lebih dari metode omnibus law karena setiap rancangan akan dibahas satu-persatu. Cognate Bills merupakan proses legislasi dua atau lebih rancangan peraturan (bill) yang saling berkaitan dari segi muatan materi subjeknya, yang diajukan ke parlemen secara bersamaan sebagai satu paket, tapi tetap berbentuk rancangan yang terpisah (Juwana et al., 2020). Dengan metode ini dapat menjadi solusi atas rekonstruksi hukum sebagai upaya harmonisasi peraturan perundang-undangan pada sektor pendidikan.

Rekonstruksi hukum pada sektor pendidikan dengan menggunakan metode Cognate Bills dalam hal ini adalah dengan mengajukan rancangan undang-undang yang saling berkaitan dari segi muatan subjeknya seperti UU Sisdiknas, Undang-Undang Guru dan Dosen, UndangUndang Pendidikan Tinggi, dan UU Ciptaker yang memiliki keterkaitan subjek pada sektor pendidikan. Legislator dapat melihat keterkaitan antara peraturan perundang-undangan yang satu dengan yang lain, yang dibahas dalam satu paket secara bersamaan, tapi tetap menjadi rancangan terpisah yang dibahas satu-persatu, sehingga hal ini dapat menjadi sarana untuk melakukan harmonisasi peraturan perundang-undangan pada sektor pendidikan, baik secara horizontal maupun secara vertikal. Selain itu, berbeda dengan metode omnibus law yang hanya menarik benang merah dari beberapa UU yang terkait dengan menciptakan UU baru yang tentunya akan mengubah struktur masing-masing UU. Metode Cognate Bills ini hanya akan melakukan sinkronisasi dan harmonisasi pada beberapa peraturan perundang-undangan yang 
terkait dari segi muatan materi subjeknya. Oleh karena itu, harmonisasi peraturan perundangundangan di bidang pendidikan dengan mengakomodasikan pengaturan terkait sistem pembelajaran hibrida melalui metode Cognate Bills merupakan sarana pembangunan dan pembaharuan masyarakat, serta bentuk penyelesaian permasalahan-permasalahan yang terjadi dalam sektor pendidikan.

\section{Kesimpulan}

Berdasarkan dari hasil penelitian di atas, dapat ditarik beberapa kesimpulan sebagai berikut:

a. Sistem pembelajaran hibrida merupakan sistem pembelajaran yang mengintegrasikan instruksi pembelajaran tatap muka dengan pembelajaran daring menggunakan platform teknologi informasi dan komunikasi sebagai sarana pendukung, yang dapat menjadi solusi yang inovatif untuk meningkatkan akses keterjangkauan masyarakat pada kualitas pendidikan di Indonesia. Selain itu, sistem pembelajaran hibrida dapat meningkatkan inklusi pendidikan di Indonesia dengan menghilangkan batas-batas geografis melalui pengimplementasian sarana teknologi informasi dan komunikasi. Konsep penerapan sistem pembelajaran hibrida dilakukan secara simultan dan dapat didukung secara asinkron. Akan tetapi, dalam penerapannya terdapat tantangan dan hambatan terkait dengan sistem pembelajaran hibrida yang berkelanjutan, yaitu seperti adanya kesenjangan akses teknologi antara masyarakat perkotaan dengan masyarakat pedesaan; iklim pembelajaran yang kurang baik; serta disharmonisasi regulasi sektor pendidikan. Namun, tantangan dan hambatan yang ada dapat dihadapi dengan komitmen KOMINFO dalam membangun infrastruktur digital yang kuat dan inklusif, kerja sama antar stakeholders dalam sektor pendidikan, serta melakukan harmonisasi peraturan perundangundangan di sektor pendidikan.

b. Rekonstruksi peraturan perundang-undangan di bidang pendidikan dengan mengakomodasikan pengaturan sistem pembelajaran hibrida yang berkelanjutan merupakan manifestasi dari hakikat pendidikan sebagai satu kesatuan yang harmonis dan terpadu, guna menciptakan tatanan hukum menjadi tersusun secara sistematis dan tidak saling bertentangan satu sama lain. Upaya rekonstruksi hukum tersebut dilakukan dengan melakukan harmonisasi peraturan perundang-undangan yang terkait dengan bidang pendidikan menggunakan metode Cognate Bills yang kemudian dilakukan dengan sinkronisasi pada beberapa peraturan perundang-undangan dari segi muatan materi subjeknya.

Berdasarkan hasil analisa pembahasan dan kesimpulan yang telah dijabarkan, maka terdapat saran dan rekomendasi dari penulis terkait dengan "Digitalisasi Sistem Pendidikan dengan Menerapkan Pembelajaran Hibrida Melalui Rekonstruksi Hukum Menggunakan Metode Cognate Bills", yaitu antara lain: 
Jurnal Yustika

Vol. 24 No. 02, Des 2021

Halaman | 117

Digitalisasi Sistem

Pendidikan Dengan

Menerapkan

Pembelajaran

Hibrida Melalui

Rekonstruksi

Hukum

Menggunakan

Metode Cognate

Bills

Candya Upavata Kutey

Karta Negara, Daeli

Subrianty, Kamelia Desi

Awaliah
1. Diperlukan adanya penelitian lebih lanjut terkait dengan teknis pembelajaran hibrida untuk diterapkan di Indonesia secara berkelanjutan sebagai upaya peningkatan inklusi pendidikan yang berkualitas.

2. Diperlukan adanya sinergi dari seluruh stakeholder terkait, untuk merealisasikan penerapan pembelajaran hibrida yang berkelanjutan.

3. Lembaga legislator diharapkan untuk melakukan rekonstruksi hukum dalam rangka perbaikan sistem hukum pendidikan dan untuk mengakomodasi pembelajaran hibrida yang berkelanjutan melalui harmonisasi hukum menggunakan metode Cognate Bills sebagai proses legislasi yang dapat dilakukan.

\section{Daftar Referensi}

\section{Peraturan Perundang-undangan:}

Undang-Undang Dasar Negara Republik Indonesia Tahun 1945

Peraturan Pemerintah Nomor 48 Tahun 2005 tentang Pengangkatan Pegawai Negeri Sipil

Undang-Undang Nomor 11 Tahun 2020 tentang Cipta Kerja

Undang-Undang Nomor 20 Tahun 2003 tentang Sistem Pendidikan Nasional

Buku:

Ahmad Avenzora (2020). Statistik Pendidikan 2020. Jakarta: Badan Pusat Statistik.

Andreas Schleicher. (2019). PISA 2018: Insight and Interpretations. Paris: OECD.

Bryan A. Garner. (2018). Black Law Dictionary. ST. Paul Minn: West Group

Hans Kelsen (1978). Pure Theory of Law. California: Berkeley University of California Press.

Stephanie Juwana et al. (2020). Sistem dan Praktik Omnibus Law di Berbagai Negara dan Analisis RUU Cipta Kerja Dari Perspektif Good Legislation Making. Jakarta: Indonesia Ocean Justice Initiative.

Jurnal:

Artikel Jurnal:

Argama, R. (2020). Kertas Advokasi Kebijakan Atas UU No 11 Tahun 2020 Tentang Cipta Kerja, Publikasi Pusat Studi Hukum dan Kebijakan Indonesia. 11, 1-26.

Bibi, Sarah (2015). Efektivitas Model Blended Learning Terhadap Motivasi dan Tingkat Pemahaman Mahasiswa Mata Kuliah Algoritma dan Pemrograman. Jurnal Pendidikan Vokasi, 5(1), 74-87.

Driscoll, M. (2002). Blended learning: Let's get beyond the hype. E-learning, 1(4), 1-4.

Fauzan \& Fatkhul Arifin (2017). Hybrid Learning sebagai Alternatif Model Pembelajaran. Conference: Seminar Nasional: Profesionalisme Guru di Era Digital At: Fakultas Ilmu Tarbiyah dan Keguruan UIN Syarif Hidayatullah Jakarta. Available online from: 
https://www.researchgate.net/publication/344361017_Hybrid_Learning_sebagai_Alternatif_Mode

l_Pembelajaran_Fauzan_Fatkhul_Arifin. [Accessed July 9, 2021].

Jurnal Yustika

Vol. 24 No. 02, Des 2021

Hwang, A. (2018). Online and hybrid learning. Journal of Management Education, 42(4), 557-563. https://doi.org/10.1177/1052562918777550

Halaman | 118

Jamilah A. Alokluk (2018). The Effectiveness of Blackboard System, Uses and Limitations in Pendidikan Dengan

Information Management. Intelligent Information Management, 10, 133-149. doi: https://doi.org/10.4236/iim.2018.106012

Menerapkan

Pembelajaran

Hibrida Melalui

Rekonstruksi

Hukum

Menggunakan

Metode Cognate

Bills

Candya Upavata Kutey

Karta Negara, Daeli

Subrianty, Kamelia Desi

Awaliah 